\title{
Random Amplified Polymorphisms Between Two South American Subspecies of Rattlesnakes (Crotalus durissus collilineatus and Crotalus durissus terrificus)
}

\author{
Sergio Echeverrigaray ${ }^{1 *}$; Gilberto Grazziotin; Felipe Grazziotin and Gustavo Agostini \\ Departamento de Ciências Biológicas, Universidade de Caxias do Sul, CP 3152, CEP 95001-970, Caxias do Sul - \\ RS, Brazil
}

\begin{abstract}
The present work was made to determine the suitability of RAPD analysis for the identification of specimens of two subspecies of South American rattlesnakes (Crotalus durissus terrificus and Crotalus durissus collilineatus). The 11 arbitrary primer sequence tested amplified a total of 161 bands, of which $31 \%$ were polymorphics when compared with Crotalus specimens. The combining results from different primers allowed the identification of all the specimens under analysis. Several characteristic bands of each subspecies were identified. Dendrogram, based on RAPD markers, show three groups that corresponded to the subspecies of Crotalus, and to Bothrops jararaca specimen.
\end{abstract}

Key words: Rattlesnake, RAPD, genetic variability, molecular markers

\section{INTRODUCTION}

The snakes of the genus Crotalus originated in North America migrated to Central and South America. Central and South American rattlesnakes are classified as a single species, Crotalus durissus, which is separated by several authors into various subspecies (Campbell and Lamar, 1989). Based on the geographical distribution and several morphological traits such as the pattern of longitudinal bands on the neck, the presence of more or less contrasting rhomboid blotches, the shape and intensity of paravertebral nuchal stripes and the presence of loreal scales, Peter and OrejaMiranda (1970) separated Crotalus durissus in the following subspecies: C.d.durissus, C.d. terrificus, C.d. unicolor, C.d. collilineatus, C.d. cascavela,
C.d. ruraima, C.d. dryinus, C.d. tzabcan, C.d. marajoensis and C.d. cumanensis.

The separation of Crotalus durissus into different subspecies raises a conceptual argument, since it is difficult to guarantee the existence of these subspecies based on a few morphological characters, most of which exhibit a large variation within each group (Santos and Laporta Ferreira, 1992). Nevertheless, the comparative analysis of venom composition has confirmed the existence of at least two subspecies, C.d. durissus and C.d. terrificus, and several groups within the last one (Barrio, 1960).

Four of the subspecies of $C$. durissus are found in Brazil: C.d. marajoensis, restricted to the Marajo island, C.d. carcavela, found in the dry region of the northeast of Brazil, C.d. collilineatus, distributed from central Brazil to north Argentina,

\footnotetext{
* Author for correspondence
} 
and C.d.terrificus, spread over the south of Brazil, Argentina and Uruguay (Hoge, 1965; Hoge and Romano-Hoge, 1979; Campbell and Lamar, 1989). The last two subspecies have a sympatric region distribution on southeast Brazil.

The molecular approaches utilizing genomic DNA have revolutionized the studies of ecology, evolution, population genetics and systematics. Identification of restriction fragment length polymorphisms (RFLP), DNA sequence disparities, DNA fingerprintings, and random amplified polymorphic DNA (RAPD) have been used to distinguish among individuals, populations, species and higher taxa, ant to evaluate phylogenetic relationships in plants, animals and microorganisms (Burke and Bruford, 1987, Parker and Whiteman, 1993, Master, 1995). In an attempt to better characterized two subspecies of Crotalus durissus: C. $d$. terrificus and $C . d$. collilineatus, we investigated molecular differences between individuals of both subspecies, based on random amplified polymorphic DNA markers.

\section{MATERIALS AND METHODS}

Eight adult snakes were used in the present study. Three were representatives of $C . d$. collilineatus from central Brazil (Goias and Mato Grosso states), four were representatives of $C$. d. terrificus from south Brazil (Rio Grande do Sul state), and one representative of Bothrops jararaca, used as a pattern of intergeneric variation. All the animals were collected in different locations. All this individuals are part of the collection of the Museum of Natural Sciences of the University of Caxias do Sul.

Blood samples from each individual, collected by the cardiac puncture method described by Branch (1973), were stored at $-20^{\circ} \mathrm{C}$ prior to DNA purification. Total DNA was extracted according to procedures adapted from Hillel et al. (1989). A $0.1 \mathrm{ml}$ blood aliquot was mixed with $0.4 \mathrm{ml}$ of $1 \mathrm{xSSC}$ and homogenated with an equal volume of phenol:chloroform:isoamyl alcohol (50:48:2). The suspension was centrifuged at $13000 \mathrm{xg}$ for five minutes at $4^{\circ} \mathrm{C}$. The layer was transferred to a clean tube and subjected to a second extraction by the addition of an equal volume of chloroform:isoamyl alcohol (24:1) followed by mixing and centrifugation as described above.

The DNA present in the aqueous layer was precipitated by the addition of two volume of ethanol $\left(-20^{\circ} \mathrm{C}\right)$, followed by at least one hour incubation at $-20^{\circ} \mathrm{C}$. The DNA was pelleted by centrifugation at $13000 \mathrm{xg}$ for five minutes at $4^{\circ} \mathrm{C}$, air dried at room temperature and dissolved in $400 \mu \mathrm{l}$ of TE (pH8.0). The DNA was precipitated again by the addition of $4 \mu \mathrm{l}$ of $\% \mathrm{M}$ sodium acetate and $1 \mathrm{ml}$ of ethanol $\left(-20^{\circ} \mathrm{C}\right)$, pelleted by centrifugation at $13000 \mathrm{xg}$ for five minutes at $4^{\circ} \mathrm{C}$, air dried and dissolved in 50 $\mu$ l of TE. DNA concentration and purity was measured by spectrophotometry at $\mathrm{A}_{260}$ and $\mathrm{A}_{280}$. The extracted DNAs were stored at $-20^{\circ} \mathrm{C}$ until used for DNA amplification.

DNA amplifications were carried out in an MJ Research, Inc. MiniCycler using the method described by Williams et al. (1993). The amount of template DNA was of $100 \mathrm{ng}$ per reaction. Taq DNA polymerase was obtained from Pharmacia Co. Primers were obtained from Operon Technologies, Inc. In the course of the study, 60 primers of the kits OPB, OPX and OPY were evaluated. Each RAPD amplification was prepared at least three times to determine reproducibility of the patterns. Amplification products were electrophoresed through $1.5 \%$ agarose gels in 1xTBE, stained with ethidium bromide and visualized under UV light.

Amplification products were listed as discrete character states per strain (present/absent). These data were analyzed using the NTSYS-pc (Numerical Taxonomy and Multivariate Analysis System) package, version 1.5 (Rohlf, 1989) to determine the similarities among the individuals. Similarities were computed using the Jaccard's coefficient. The individuals were clustered by the unweighted pair-group method using arithmetic averages (UPGMA) in order to present the results in the form of a phenogram.

\section{RESULTS AND DISCUSSION}

From the 60 primers evaluated for the generation of amplified DNA products of specific size from rattlesnakes, 18 primers provided more than three scorable bands and were selected for the studies. A 
fragment was judged to be scorable if it was intense enough and different enough in size from neighboring bands to be scored with confidence, as well as being reproducible from experiment to experiment. From these 18 primers, 11 generated reproducible markers with some degree of variability between the individuals. The other seven primers generated markers that were highly conserved among the Crotalus specimens examined.
The selected primers (Table 1) generated a total of 161 scorable amplification products that were analyzed and used as variables in our analysis. The variation between Crotalus and Bothrops was higher than the variation between the two subspecies of Crotalus durissus (Fig.1 and Fig.2). Of the selected bands, $83.9 \%$ were polymorphics between Crotalus and Bothrops, what was expected when comparing different genera.

Table 1 - Primers identification and corresponding number of scorable, polymorphic and specific bands, amplified form rattlesnake DNA. (Cdt - C. d. terrificus, Cdc- C. d. collilineatus)

\begin{tabular}{llcrcc}
\hline Primer $^{\mathrm{a}}$ & $\begin{array}{l}\text { Primer sequence } \\
5^{\prime}>3\end{array}$ & $\begin{array}{l}\mathrm{N}^{\mathbf{c}} \\
\text { bands }\end{array}$ & $\begin{array}{l}\text { scorable } \\
\text { Polymorphic } \\
\text { bands }\end{array}$ & $\begin{array}{l}\text { Specifics of } \\
\text { Cdt }\end{array}$ & Specifics of Cdc \\
\hline OPB-04 & GGACTGGAGT & 04 & 01 & 0 & 1 \\
OPB-08 & GTCCACACGG & 21 & 02 & 0 & 1 \\
OPB-10 & CTGCTGGGAC & 30 & 14 & 0 & 2 \\
OPB-13 & TTCCCCCGCT & 05 & 02 & 0 & 0 \\
OPX-01 & CTGGGCACGA & 16 & 06 & 1 & 1 \\
OPX-03 & TGGCGCAGTG & 10 & 03 & 2 & 0 \\
OPX-06 & ACGCCAGAGG & 24 & 05 & 2 & 0 \\
OPX-11 & GGAGCCTCAG & 12 & 05 & 5 & 0 \\
OPX-13 & ACGGGAGCAA & 16 & 06 & 0 & 0 \\
OPY-01 & GTGGCATCTC & 08 & 01 & 1 & 0 \\
OPY-02 & CATCGCCGCA & 15 & 04 & 0 & 3 \\
\hline
\end{tabular}

${ }^{\mathrm{a}}$ Primer designation refers to the kit (last letter) and the specific primer (number) purchase form Operon Techn.

Conversely, only 50 bands (31\%) were polymorphics when comparing the seven specimens of Crotalus. From these, 31 bands showed a random polymorphism distribution among the individuals of both subspecies allowing for the identification of all the specimensThese band patterns could be useful in population studies, but were not able to discriminate between the subspecies. The remaining 19 bands $(38 \%)$ of the polymorphic bands between Crotalus specimens were specifics of each subspecies. Eight bands were

present only in the four specimens of $C . d$. collilineatus, and 11 were specific of C.d. terrificus. One of these specific bands can be observed in Figure 1.

The 161 RAPD fragments were used to calculate similarity values and to estimate the relatedness among the specimens. As can be observed in Table 2 , the similarity between individuals of the same subspecies ranged from 0.98 and 0.87 . These values were very high when compared with the interespecific variation obtained in other organisms
(Ferreira and Grattapaglia, 1996). This results supported their separation in sub-species.

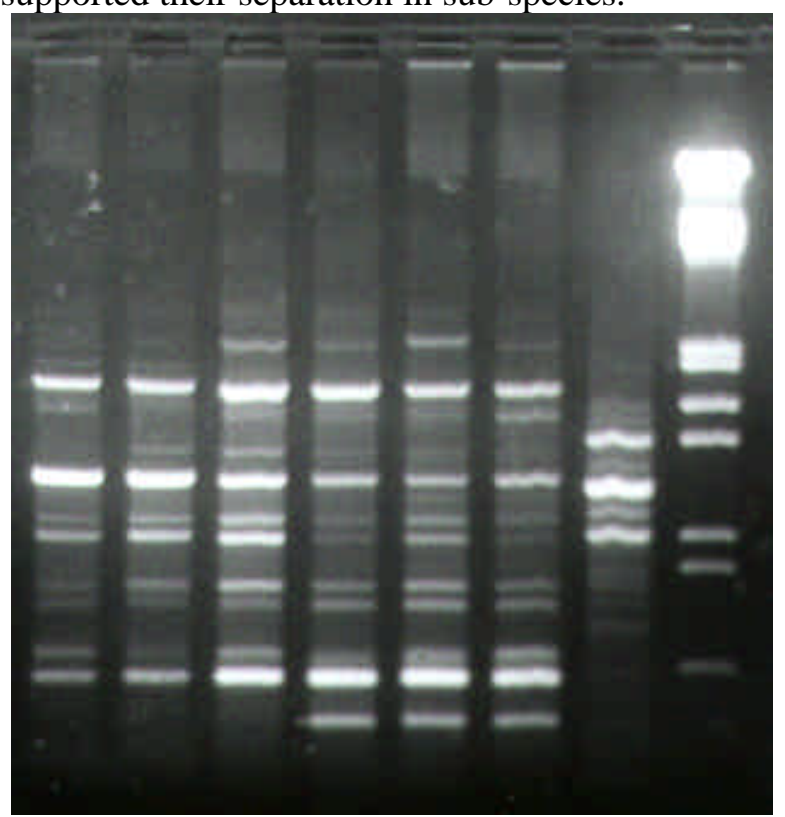

Figure 1 - RAPD products generated using primers OPB-08. Lanes 1-3, specimens of C.d. terrificus, lanes 
4-6, specimens of C.d. collilineatus, lane 7, a specimen of $B$. jararaca, and lane 8, DNA size standard $(\lambda /$ EcoRI-HindIII fragments).

Table 2 - Distance matrix between each of eight specimens of snakes, based on their RAPD profiles. Cdt - C. d. terrificus, Cdc- C. d. collilineatus, BjBothrops jararaca.

\begin{tabular}{lccccccc}
\hline $\mathrm{Cdt}$ & $\mathrm{Cdt}$ & $\mathrm{Cdt}$ & $\mathrm{Cdt}$ & $\mathrm{Cdc}$ & $\mathrm{Cdc}$ & $\mathrm{Cdc}$ & $\mathrm{Bj}$ \\
\multicolumn{1}{c}{1} & 2 & 3 & 4 & 1 & 2 & 3 & \\
\hline 1.0 & & & & & & & \\
0 & & & & & & & \\
0.9 & 1.00 & & & & & & \\
4 & & & & & & & \\
0.9 & 0.93 & 1.00 & & & & & \\
1 & & & & & & & \\
0.8 & 0.92 & 0.93 & 1.00 & & & & \\
8 & & & & & & & \\
0.7 & 0.83 & 0.82 & 0.85 & 1.00 & & & \\
9 & & & & & & & \\
0.7 & 0.82 & 0.79 & 0.83 & 0.96 & 1.00 & & \\
8 & & & & & & & \\
0.8 & 0.83 & 0.80 & 0.84 & 0.96 & 0.98 & 1.00 & \\
0 & & & & & & & \\
0.3 & 0.34 & 0.32 & 0.33 & 0.34 & 0.34 & 0.35 & 1.00 \\
3 & & & & & & & \\
\hline
\end{tabular}

The similarity between individuals of C.d. terrificus and C.d. collilineatus ranged from 0.78 and 0.85 . These values were slightly lower than those obtained between individuals of the same subspecies, allowing separating them in two populations. The similarity values between Crotalus and Bothrops were of the order of 0.33 .

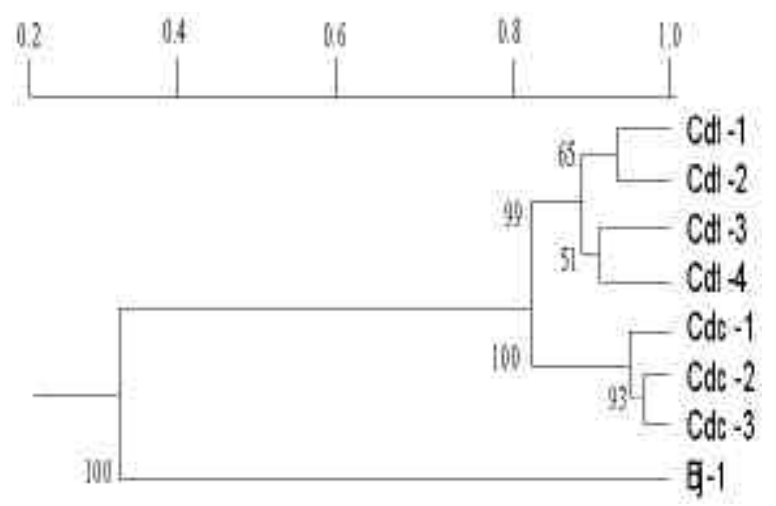

Figure 2- Similarity tree based on the shared bands in pairwise comparisons using UPGMA and Jaccard's distances. Cdt $-C . d$. terrificus, Cdc- $C . d$. collilineatus, $\mathrm{Bj}$ - Bothrops jararaca.

The similarity matrix was used to generate a phenogram (Figure 2). Expectedly, Crotalus and Bothrops were clustered in different groups with low relation between them. The phylogenetic tree showed that the Crotalus specimens clearly form two separate groups that corresponded to the two subspecies studied in this work. The lowest similarity among individuals of each group was $92 \%$, while the similarity between groups was $81 \%$.

Considering that each specimen represented a different genetic pool and, as a whole, they gave a good estimative of the genetic variability of each subspecies, the present data supported the separation of $C$. durissus, into C.d. terrificus and C.d. collilineatus. Moreover, this molecular markers would be useful to confirm the crosses between the two subspecies in the sympathric region (São Paulo state), reported by Hoge (1965) and Santos and Laporta Ferreira (1992), and to evaluate the gene flow between them.

\section{ACKNOWLEDGEMENTS}

We thanks the University of Caxias do Sul for the financial support of this work, and FAPERGS and $\mathrm{CNPq}$ for the scholarships of $\mathrm{G}$. Agostini and F. Grazziotin, respectively.

\section{RESUMO}

O presente trabalho foi desenvolvido visando determinar a aplicabilidade da análise de RAPD na identificação de indivíduos pertencentes a duas subespécies de cascavéis sul-americanas (Crotalus durissus terrificus e Crotalus durissus collilineatus). As 11 sequências arbitrárias inicializadoras testadas nestes experimentos, amplificaram um total de 161 bandas, das quais $31 \%$ foram polimórficas na comparação entre espécimes de Cratalus. Os resultados combinados 
obtidos com as distintas sequências inicializadoras, permitiram a identificação de todos os indivíduos avaliados. Várias bandas características de cada sub-espécie foram identificadas. O dendrogama, baseado em marcaodres de RAPD, mostra tres grupos que correspondem às duas sub-espécies de Crotalus e ao especimen de Bothrops jararaca.

\section{REFERENCES}

Barrio, A. (1960), Consideraciones en torno a Crotalus durissus terrificus crotaminicus Moura Gonçalves. Physis (Buenos Aires) 22, 141-147

Branch, B. (1973), The collection of blood by cardiac puncture from surgically anesthetized snakes. J. Herp. Assoc. Africa. 11, 5-6

Burke, T. and M. W. Bruford (1987), DNA fingerpinting of birds. Nature. 327, 149-152

Campbell, J. A and W. W. Lamar (1989). The venomous reptiles of Latin America. Cornell Univ. Press, Ithaca, N.Y., 425

Duellmann, W. E. (1979), The South American herpetofauna: its origin, evolution and dispersal. W.E. Wuellmann, Ed., Monogr. Mus. Nat. Hist., Univ. Kansas, $\mathrm{n}^{\circ} 7$.

Ferreira, M. E., and D. Grattapaglia. (1996), Introdução ao uso de marcadores moleculares em análise genética. 2 ed. EMBRAPA-CENARGEM,
Hillel, J., T. Schaap, A Haberfield, A J Jeffrey, Y. Plotzky, A Cahaner and U. Lavi. (1989), DNA fingerprinting of poultry. Animal Genetics 20, 25-35

Hoge, A. R. (1965), Preliminary account on Neotropical Crotalinae (Serpentes, Viperidae). Mem. Inst. Butantan. 32, 109-184

Hoge, A. R. and S. A. R. W. D. L. Romano-Hoge (1979), Sinopse das serpentes peçonhentas do Brasil. Mem. Inst. Butantan. 42/43, 373-496

Master, B. S. (1995), The use of RAPD markers for species identification in demognathine salamanders. Herpetol. Ver. 26, 92-95

Peters, J. A and B. Oreja-Miranda (1970), Catalogue of the Neotropical Squamata: Part I. Snakes. Bull. U.S. Natl. Mus. 297, 1-347

Rohlf, F. J. (1989), NTSYS-pc numerical taxonomy and multivariate analysis system, version 1.70 . Exeter Software, Setauket, N.Y.

Santos, S. and I. L. Laporta Ferreira. (1992), Discriminação geográfica de Crotalus durissus terrificus and Crotalus durissus collilineatus no Estado de São Paulo. Res. Congr. Latino-Americano de Zoologia, Belém, PA, Brasil, 123.

Williams, J. G. K.; J. A. Rafalski and S. V. Tingey. 1993. Genetic analysis using RAPD markers. Methods Enzymol. 218, 704-740

Received: April 22, 1999;

Revised: April 26, 1999; Acceped: November 18, 2000. 